\title{
Analysis on Performance Management of Financial Funds in China's Higher Education
}

\author{
Xiaohua Ning \\ Development Planning Office, Central University of Finance and Economics, Beijing, China \\ Email address: \\ Ningxiaohua916@126.com \\ To cite this article: \\ Xiaohua Ning. Analysis on Performance Management of Financial Funds in China's Higher Education. Higher Education Research. \\ Vol. 4, No. 6, 2019, pp. 87-96. doi: 10.11648/j.her.20190406.13
}

Received: December 10, 2019; Accepted: December 18, 2019; Published: December 26, 2019

\begin{abstract}
As an effective educational management tool, budget performance management in colleges and universities has become an important basis and management means for allocating educational resources and formulating corresponding educational policies. It plays an important role in promoting colleges and universities to improve their management level, cultivate outstanding talents and serve social development. In recent years, with the rapid development of higher education in our country, the financial expenditure in the field of education has gradually increased, the government departments have continuously increased their investment in financial education funds, and the state's investment in higher education has also increased year by year. In addition, with the reform of the "performance-oriented" financial expenditure management system, the relevant departments in China have also strengthened the performance management of colleges and universities. This paper sorts out the practice of financial fund performance evaluation in higher education at central and local levels in China since 1988, summarizes the experience and practice of financial fund performance evaluation in higher education in China, and thinks that further improvement is needed in legal system, evaluation consciousness, evaluation scope, evaluation index, evaluation subject, evaluation content and application of evaluation results, hoping to have certain reference value for improving the financial fund performance management in higher education in China.
\end{abstract}

Keywords: Higher Education, Financial Funds, Performance Management

\section{Introduction}

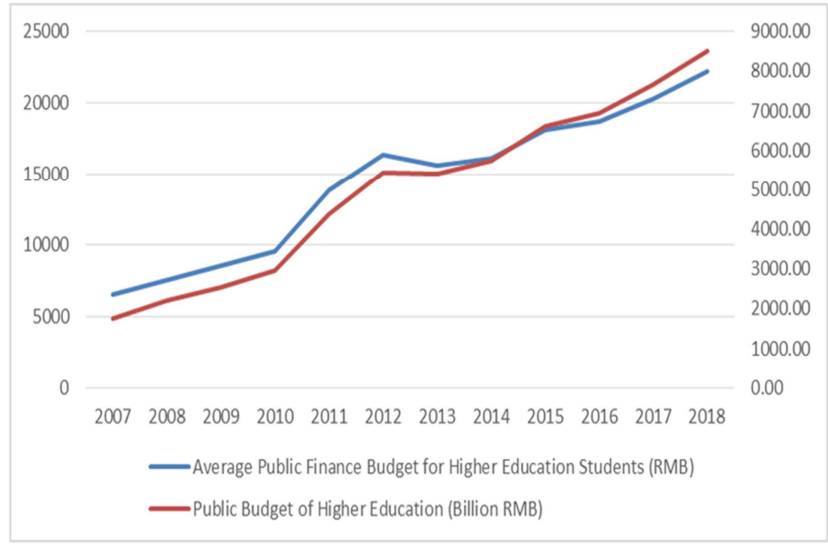

Source: Ministry of Education website: http://www.moe.gov.cn/jyb_sjzl/.

Figure 1. Public Finance Budget for Higher Education in China in Recent Years.
In recent years, with the rapid development of higher education in China, the financial expenditure in the field of education has gradually increased, the government departments' investment in financial education funds has increased continuously, and the state's investment in higher education has also increased year by year. Both the average public financial budget for students and the total investment in education funds are on the rise (see figure 1). In addition, with the reform of the "performance-oriented" financial expenditure management system, the relevant departments in China have also strengthened the performance management of colleges and universities. As an effective educational management tool, budget performance management in colleges and universities has become an important basis and management means for allocating educational resources and formulating corresponding educational policies. It plays an important role in promoting colleges and universities to improve their management level, cultivate outstanding talents and serve social development. This paper combs and 
analyzes the practical exploration, experience and existing problems in the performance evaluation of financial funds in the field of higher education in China, hoping to have some reference value for improving the performance management of financial funds in the field of higher education in China.

\section{Practical Exploration on Performance Evaluation of Financial Funds in Higher Education}

\subsection{Practice of Performance Evaluation of Financial Funds in Higher Education at Central Level}

As early as 1988, the Ministry of Finance implemented a tracking and feedback responsibility system for education and other special funds. In order to further strengthen the management of public funds and improve the efficiency of the use of public funds, in 1992, the Ministry of Finance formulated the "Trial Implementation of Measures for Evaluating the Effectiveness of the Use of Social, Cultural and Educational Administrative Funds" [1], which specified in detail the assessment principles, assessment scope, assessment index system, assessment methods, assessment work management and authority, as well as the supervision and inspection of assessment and other related matters, to a certain extent reflecting the management thinking of performance evaluation. With the active promotion of the Ministry of Finance, the system of drawing up the annual education fund demand plan has been gradually implemented throughout the country since 1994. The education administrative departments at all levels are responsible for preparing the annual demand plan, reporting it to the finance department at the same level for examination and approval, and implementing it after being approved by the local people's congress. This reform has played a positive role in the finance department's comprehensive understanding of the supply and demand of education funds at all levels and ensuring the effective use of education financial expenditure.

In 1995, the State Education Commission and the National Bureau of Statistics issued the "Monitoring System for the Implementation of National Education Funds" [2], formally establishing the monitoring system for the implementation of education funds. The national monitoring system supervises and reviews the implementation of education funds and the implementation effect of expenditure items by governments at all levels according to the relevant provisions on financial education expenditures in the Outline of China's Education Reform and Development, the Compulsory Education Law of the People's Republic of China and the Education Law of the People's Republic of China.

In 1995, in order to strengthen cultural and educational administration and financial management and improve the efficiency of the use of funds, the Ministry of Finance formulated the "Measures for Evaluating the Efficiency of Cultural and Educational Administration and Financial Management and the Use of Funds" [3]. For the first time, documents were used to refer to the efficiency management of educational funds.

From 1995 to 1996, the state evaluated the key construction plans of about 100 universities and many key disciplines in the "211" project, and officially launched the "211" project. In 2001, the "211 Project" construction project was evaluated for acceptance.

In 1998, according to the "Financial Rules for Public Institutions" and the "Financial Rules for Administrative Units", the Ministry of Finance revised the original "Measures for Evaluating the Efficiency of Cultural and Educational Administrative Financial Management and Use of Funds". The main contents of the new "Measures" clearly defined the purpose, principles, objects and grades of the benefit evaluation.

In 1998, the General Office of the State Education Commission issued "Key Points of Education Audit Work in 1998" [4], stipulating that all institutions of higher learning and other educational institutions should seriously organize audit institutions to carry out audits of the budget implementation of their own schools and units, with a focus on examining whether all funds within and outside the budget are included in budget management, how effective they are in use, and whether there is any loss or waste. At the same time, colleges and universities should also organize audit institutions to carry out special audit investigations on the management and use of scientific research funds, especially on the benefits. All institutions of higher learning that implement joint management in the institutions of higher learning should organize audit institutions to audit the assets, liabilities and net assets of each school to prevent the loss of state-owned assets and other violations of discipline. Institutions of higher learning that have entered the "211 Project" should organize audit institutions to conduct followup audits of the management and use of special funds for the project.

In the same year, the Ministry of Education issued the Circular on Cross-checking the Implementation of the Circular on Further Making Budget Arrangements for Educational Science and Technology Funds and Ensuring Timely Payment of Teachers' Wages, which was forwarded by the General Office of the State Council to the Ministry of Finance, requiring all localities to organize and lead a comprehensive cross-check on the use of educational funds in accordance with the budget levels and submit a report on the situation to the Ministry of Education.

In 2000, the Ministry of Education issued "Several Opinions on Establishing Economic Responsibility System and Strengthening Financial Management in Colleges and Universities" [5], requiring colleges and universities to gradually establish and improve economic responsibility systems at all levels, further strengthen budget management, effectively strengthen financial management and supervision of secondary units, and standardize the operations of settlement centers in schools.

At the same time, the Ministry of Education also organized experts to conduct research on the evaluation of university 
expenditures in 1998 and 2000 respectively, and included four funds in the evaluation index of undergraduate teaching evaluation, of which the index " $\mathrm{A}$ " requires that the proportion of four funds in tuition income is more than $30 \%$.

In 2002, the Ministry of Education put forward a performance funding plan for the "985" project, "Proposal for Evaluation and Funding Plan for High-level Universities", in order to design a performance funding model for universities and optimize the allocation of university resources.

In 2003, the Ministry of Finance's Educational, Scientific and Cultural Department took the lead in piloting 7 project funds of the central-level educational, scientific and cultural department, and formulated corresponding performance evaluation management methods and performance evaluation indicators. In 2004, the pilot project was expanded to 11 projects.

In September 2005, the Ministry of Finance issued the "Administrative Measures for Project Performance Evaluation of Educational, Scientific and Cultural Departments at the Central Level" [6], which requires a comprehensive evaluation and evaluation of the implementation process and the results of special fund projects of educational, scientific and cultural departments incorporated into the budget management of central departments. The scope of evaluation mainly includes: special planning projects (i.e. special plans, projects and fund projects approved by the state for the development of educational, scientific and cultural undertakings), special business projects, and large-scale renovation and purchase projects. The "Measures" have made corresponding provisions on the indicators, contents, implementation and application of results of performance evaluation.

In December 2009, the "Performance Evaluation Report of Chinese Higher Education" completed by the Higher Education Research Center of the State-level Comprehensive Educational Science Research Institution directly under the Ministry of Education of the Central Institute of Education was the first performance evaluation of universities directly under the Ministry of Education. The report is of great significance for enriching the content and methods of university evaluation and rationally allocating university resources.

In 2010, the Office of the Working Group on the National Medium-and Long-Term Education Reform and Development Plan released the National Medium-and LongTerm Education Reform and Development Plan (2010-2020), pointing out the need to set up a higher education funding advisory committee to enhance the scientific allocation of funds. The post of chief accountant will be set up on a trial basis in institutions of higher learning to raise the level of specialization in the use of funds and asset management. The chief accountant of public institutions of higher learning is appointed by the government. It should strengthen supervision over the use of funds, intensify audits of major project construction and the whole process of the use of funds, and ensure that the use of funds is standardized, safe and effective, establish and continuously improve the basic information base of education funds, and improve the informatization level of fund management. At the same time, it also should establish a performance evaluation system for the use of funds and strengthen the evaluation of the use of funds for major projects.

In 2011, the circular of the general office of the Ministry of education on the implementation of the method of linking the budget of subordinate colleges and universities with the budget implementation [7] and the circular of the Ministry of finance on the implementation of the method of linking the performance allocation of central-level ordinary colleges and universities with the budget implementation of project expenditure [8] were issued, strengthening the safety, standardization and effective management of the use of financial funds in colleges and universities.

In June 2012, the Ministry of Education issued the 12th Five-Year Plan for the Development of National Education [9], explicitly proposing the establishment of a higher education funding advisory committee, the improvement of the performance evaluation system of financial expenditure in higher education institutions, and the construction of a performance-oriented resource allocation mechanism. We should comprehensively promote scientific and fine management of education funds, strengthen the management of school budget and improve the management level of school funds. and strengthen the supervision of funds, strict education funds audit system, improve the financial disclosure system, to ensure that all levels of government and schools to make good use of education funds and give full play to the maximum benefit.

In September 2012, the Ministry of Finance issued the Performance Budget Management Plan (2012-2015) [10] and two supporting documents, requiring the gradual establishment of a budget performance evaluation index system in line with China's national conditions, continuously standardizing and strengthening budget performance evaluation, improving the unity and authority of performance evaluation, and comprehensively promoting budget performance management.

In 2012, the Ministry of Education and the Ministry of Finance issued the "Opinions of the Ministry of Education and the Ministry of Finance on Strengthening the Management of Scientific Research Funds in Colleges and Universities Belonging to Central Departments" [11], which pointed out that colleges and universities should improve the performance management methods of scientific research funds and establish a scientific research performance evaluation system oriented by high-level achievements and talents. in accordance with the relevant provisions, Schools can make overall use of performance expenditure, central university performance allocation, school tuition income and other funding channels in the indirect costs of scientific research funds. On the basis of performance evaluation of scientific research work, and in combination with the actual performance of scientific researchers, they may establish and improve a scientific research performance management mechanism that encourages innovation and reflects actual 
performance. At the same time, relevant departments and schools are required to take the results of special audits, midterm financial inspections, financial acceptance and performance evaluation as an important basis for project applications and budget allocation of scientific research funds.

In April 2013, the Ministry of Finance also issued the Framework of Common Indicators for Budget Performance Evaluation [12], establishing a budget performance evaluation index system in line with China's national conditions, laying a foundation for the overall promotion of budget performance management.

In 2014, the Ministry of Finance issued the Notice on Further Strengthening the Budget Implementation and Management of Fiscal Expenditure [13], pointing out that all departments should establish their own budget implementation and analysis system, establish and improve the budget expenditure responsibility system and specify the assessment indicators. Expenditure separately arranged by the same department through different budgets shall be included in the scope of assessment of implementation progress.

In the same year, the State Council's Decision on Deepening the Reform of Budget Management System [14] was issued, calling for the comprehensive promotion of budget performance management, strengthening the awareness of expenditure responsibility and efficiency, gradually extending the scope of performance management to budget units at all levels and all financial funds, expanding the focus of performance evaluation from project expenditure to the overall expenditure and policies, systems and management of departments, strengthening the application of performance evaluation results, and using evaluation results as an important basis for adjusting expenditure structure, improving financial policies and scientifically arranging budgets.

In 2015, the Measures for the Management of Budget Performance Targets of Central Departments [15] and the Opinions of the Ministry of Education on Strengthening the Internal Audit Work in Institutions of Higher Learning Directly under the Ministry of Education [16] also put forward new requirements for budget performance management in institutions of higher learning. For example, the "Opinions of the Ministry of Education on Strengthening Internal Auditing in Institutions of Higher Learning Directly under the Ministry of Education" stipulated that after the end of the budget year, the budget implementation results of institutions of higher learning should be audited, the implementation results shall be evaluated, and improvement suggestions shall be put forward. It should conduct performance audits of key projects, evaluate project performance, and promote the improvement of efficiency in the use of project funds.

In 2015, the Notice on Reforming and Perfecting the Budget Allocation System of Central Colleges and Universities [17] adjusted and perfected the budget allocation items and allocation management methods of central colleges and universities in combination with the new situation faced by the reform and development of central colleges and universities. The adjusted projects mainly include six performance grants, namely, special funds for central universities to improve basic conditions for running schools, special funds for central universities' education and teaching reform, basic research fees for central universities, special funds for central universities to build world-class universities (disciplines) and special funds for guiding characteristic development, special funds for central universities to donate matching funds, and management reform for central universities.

In 2016, the general office of the Ministry of Education issued the "Guidelines for Internal Control of Economic Activities in Colleges and Universities Directly under the Ministry of Education (Trial)", explicitly requiring colleges and universities directly under the Ministry of Education to strengthen budget performance management and establish a whole-process budget performance management mechanism that "budget preparation has objectives, budget implementation has monitoring, budget completion has evaluation, evaluation results have feedback, and feedback results have application". At the same time, colleges and universities are required to organize an audit of the implementation of the annual budget revenue and expenditure, and to include the results of the budget revenue and expenditure audit and performance evaluation into the scope of the annual assessment and economic responsibility audit of the main heads of various departments in the school.

In 2017, the "13th Five-Year Plan for the Development of National Education" [18] issued by the State Council also clearly pointed out that the management of the use of education funds and the management of state-owned assets should be strengthened. We should strengthen project library management, harden budget constraints, improve the budget performance management mechanism, strengthen the application of performance evaluation results, and ensure the maximum benefit of education funds.

In the same year, the Ministry of Finance issued the Measures for the Administration of Performance Appropriations such as the Management Reform of Central Universities [19], which requires the implementation of performance-oriented management of central universities, the transmission of clear policies and performance-oriented, the reflection of incentives and constraints, the guidance of central universities to deepen comprehensive reform, the overall improvement of management level, and the stimulation of the endogenous power and vitality of the reform and development of central universities.

\subsection{Practice of Performance Evaluation of Financial Funds in Local Higher Education}

With the introduction and promotion of some policies of the central government, various places have also made very useful explorations in the performance evaluation of higher education financial expenditure, and have set up performance budget management mechanisms in colleges and universities 
one after another, paying attention to the whole process management of performance budget.

In 2006, Beijing promulgated the Interim Measures for the Administration of Performance Evaluation of Budget Expenditure of Beijing Municipal Departments, which will gradually implement the performance evaluation of budget expenditure of departments into the agenda. In 2008, the Beijing Municipal Education Commission started the performance evaluation and testing of budget expenditures of university departments. Some universities submitted some written materials and filled in some forms as required. In 2008, Beijing issued the "Administrative Measures for Performance Evaluation of Public Institutions in Beijing (Trial)" and the "Administrative Measures for Performance Evaluation of Budget Expenditure of Information Projects in Beijing (Provisional)". Subsequently, the "Beijing Budget Performance Management Measures (Trial)", the "Beijing Municipal Budget Department Organization Financial Project Expenditure Performance Evaluation Standard", the "Beijing Financial Expenditure Performance Evaluation Implementation Rules" and the "Beijing Municipal Department Budget Management Comprehensive Assessment Measures" have been issued successively to specify the organization, indicators, contents and procedures of municipal unit performance evaluation from different angles.

As for the performance evaluation of higher education financial expenditure, Beijing mainly focuses on the management of special education expenditure, such as the implementation of a demonstration system for the allocation of special education funds and the pilot work of performance evaluation of education expenditure projects. In 2004, on the basis of conducting a pilot project on the performance evaluation of special education funds, the "Management Method for Performance Evaluation of Public Institutions in Beijing" was initially formulated. Its content is based on the principles of economy, efficiency and effectiveness, and uses a combination of quantitative and qualitative analysis to examine the completion, degree, organization and management level, economic benefits, fund implementation and actual expenditure of the project. In 2005, for the first time, Beijing conducted a full-scale pilot project performance evaluation throughout the city. After several years of exploration, Beijing has made some achievements and valuable experience in the performance evaluation of higher education expenditure.

In 2009, Shanghai also promulgated the "Implementation Plan for the" 085 "Project of Shanghai Higher Education Connotation Construction", requiring the implementation of performance evaluation or assessment on the "085" project construction of municipal universities. In 2010, Shanghai decided to carry out performance evaluation on the educational connotation construction of municipal colleges and universities, and linked the subsequent allocation with the results of performance evaluation. In 2012, the Shanghai municipal government issued the "12th Five-Year Plan" for the reform and development of Shanghai's higher education, proposing "to carry out level evaluation and performance evaluation of construction projects, to explore the implementation of a financial allocation system linked to level and performance evaluation, to rationally allocate higher education resources, to guide universities to change their school-running concepts, and to continuously improve the quality of connotation construction. In recent years, Shanghai has been improving the evaluation and consultation mechanism of special funds for higher education. One is to implement the municipal higher education special fund budget evaluation system. For projects that are included in the scope of the municipal finance special fund review, the municipal finance shall conduct a unified review, and the budget review shall be included in the project library management. The second is to implement a consultation mechanism to evaluate the expenditure of special funds for higher education. To establish an evaluation and consultation mechanism with the participation of higher education experts, government departments, NPC, CPPCC, representatives of colleges and universities, and other social stakeholders, to put forward suggestions on the direction of investment of special funds for higher education and the priorities of projects, and to put forward suggestions on the subjects undertaking competitive projects. At the same time, the government also strengthened the performance evaluation of higher education funds. One is to establish a performance tracking and evaluation system for the connotation construction funds of local colleges and universities. When preparing the budget for connotation construction funds, colleges and universities put forward performance targets and implementation paths. The Municipal Education Commission and the Municipal Finance Bureau and other departments organize mid-term evaluation and inspection, focusing on tracking the implementation progress of connotation construction projects in colleges and universities and the performance of fund use. At the end of the year, performance evaluation and assessment shall be conducted and linked to the budget for the next year. The second is to strengthen the performance evaluation of the use of major special funds. Institutions of higher learning organize or employ third-party evaluation agencies to carry out self-evaluation of project expenditure performance and performance target tracking evaluation, with emphasis on post-evaluation of major special expenditures of the university, and to combine the performance evaluation of the project with the application of the results.

In 2004, Guangdong Province issued the Interim Measures for the Management of Special Funds for Discipline Construction in Colleges and Universities in Guangdong Province, which evaluates the performance of special funds for discipline construction in colleges and universities and takes the evaluation results as the basis for fund allocation in the next year. In 2013, Guangdong Province actively promoted the formulation of an implementation plan for the project of strengthening schools through innovation in higher education and a method for awarding and supplementing funds. It integrated some and some special funds for higher 
education and set up an award and subsidy fund for the project of strengthening schools through innovation in higher education. We will reform the allocation of resources and further expand and implement the autonomy of grass-roots units and schools in running schools through "comprehensive evaluation and comprehensive award and compensation". We will enhance the vitality of running schools, guide grass-roots units and schools to strengthen macro planning and reasonable positioning, and change the past "emphasis on project application and light use management" to "emphasis on overall use of funds and strive for performance". In 2014, Governor Zhu Xiaodan of Guangdong Province gave five important instructions on the construction of high-level universities, demanding that the role of research and demonstration should be brought into full play, all affairs should be coordinated, government investment and support should be increased, and the role of performance evaluation in the construction of high-level universities should be emphasized. In 2015, Guangdong actively promoted the budget performance management mechanism, established and improved the budget performance management system of "pre-performance target review, in-process performance supervision, post-event performance evaluation and application of results" as the goal, paid attention to actual effect, took multiple measures simultaneously, continuously expanded the coverage of performance management, and actively explored and promoted the innovation of budget performance management system and mechanism. In 2015, Guangdong Province issued opinions on the construction of high-level universities, proposing to carry out the expected target construction for each university in different periods, implement the university planning, reasonably allocate resources and establish effective dynamic assessment and evaluation schemes. Colleges and universities that have successfully carried out and achieved results in performance work should be given preferential policies and financial support.

Jiangsu Province began to cooperate with Shanghai University of Finance and Economics in 2005 to carry out the pilot work of financial expenditure performance evaluation in 10 provincial universities. In 2006, the Jiangsu Provincial Department of Finance issued the "Jiangsu Province Fiscal Expenditure Performance Evaluation Measures (Trial)", which clearly stipulated the principles, scope, objects, contents and methods of performance evaluation. In December 2010, Jiangsu province issued a pilot implementation plan for the comprehensive reform of higher education, proposing to "explore the establishment of a performance allocation system, and link financial allocation with performance evaluation of universities".

In 2007, Zhejiang Province issued "Some Opinions of Zhejiang Provincial People's Government on Promoting the Development of Higher Education", proposing to link the allocation of public financial funds with teaching quality evaluation results, discipline construction results and so on, so as to fully use financial leverage to regulate the running of universities. In 2009, the Zhejiang Provincial Education
Department and the Zhejiang Provincial Department of Finance issued the Interim Measures for the Administration of Scientific Research Project Funds in Colleges and Universities in Zhejiang Province, which requires colleges and universities to establish a performance evaluation system for the use of scientific research project funds, improve the performance evaluation mechanism for the use of scientific research project funds, and scientifically evaluate the input cost and output socio-economic benefits of scientific research project funds. In 2013, in order to further establish and improve the budget performance management system of provincial education departments, promote scientific, refined and standardized financial management, and improve the performance of the use of financial funds, according to the "opinions of Zhejiang provincial people's government on comprehensively promoting budget performance management", the "opinions of Zhejiang province on the implementation of fiscal expenditure performance evaluation", the "measures for the assessment of budget performance management of Zhejiang provincial departments (trial implementation)" and other relevant documents, Zhejiang province has issued the "interim measures for the performance management of budget units of Zhejiang provincial education departments" to specify all aspects of the performance evaluation of education departments.

In addition, other places have successively carried out financial expenditure performance evaluation according to the actual situation of each place, and have been widely used in the field of higher education performance evaluation. For example, in 2010, Yunnan province also formulated the "2010 higher education development special performance evaluation work plan and index system" to carry out performance evaluation of provincial colleges and universities, and stipulated that it should be linked with the financial allocation for the next year. In 2010, Jiangxi provincial government issued "Jiangxi province financial expenditure performance evaluation scheme trial", which provides guidance for Jiangxi province higher education financial expenditure performance evaluation, and clearly stipulates six aspects such as the principle of higher education financial expenditure performance evaluation, the management and organization of evaluation, the content and method of performance evaluation, and the working procedure of performance evaluation. Anhui province started the selection of provincial quality projects in 2009 to guide colleges and universities to establish and perfect the teaching quality monitoring system, and to carry out the evaluation of ordinary undergraduate colleges and universities and the evaluation of 10 higher vocational colleges. In 2012, Hebei Province issued the "Notice of Hebei Provincial Department of Finance on Performance Evaluation of Annual Financial Expenditure Projects". The education department of Hebei Province actively carried out a number of performance evaluation activities. The provincial education department organized universities in the province to carry out performance evaluation of higher education financial 
expenditure projects and achieved remarkable results.

\section{Main Experiences and Practices}

\subsection{Adhere to the Combination of Up and Down, to Promote the Performance Evaluation Work}

First, in terms of performance management system, the central government takes the lead in formulating relevant laws and systems for performance evaluation of financial expenditures, and makes detailed provisions on the objects, contents, indicators, procedures and other elements of performance evaluation. Under the guidance of the relevant provisions on performance evaluation of higher-level departments, all localities formulate corresponding performance evaluation methods according to local actual conditions, thus ensuring the unity and continuity of performance evaluation work. Second, the scope of budget performance management extends from top to bottom. From the perspective of the central government, the scope of budget performance management gradually transits from the first-level budget department to the second-level and thirdlevel budget units. From the local point of view, budget performance management has also begun to permeate from the province to the city and county levels. Generally speaking, both the performance evaluation items and the amount of funds involved are showing a gradually expanding trend. The third is to form a top-down performance management mechanism. For example, the Ministry of Education has set up a fund supervision center of the Ministry of Education, set up an audit department in the Ministry of Education's Finance Department, strengthen supervision and improve the multi-level supervision system. Establish a work coordination mechanism. Generally, the financial department takes the lead to push the budget performance management working group, which is headed by the main leaders of the subordinate units alone or under the financial working group, assisted by the chief accountant, and participated by the financial, auditing, discipline inspection and related business departments [20].

\subsection{Adhere to the Combination of Point and Surface, Increase the Intensity of Performance Management Work}

One is to combine key evaluation with comprehensive evaluation. Since the implementation of departmental budget performance management, the types, scope and amount of funds included in budget performance management by the Ministry of Education have been expanded year by year, and performance management efforts have been continuously strengthened. According to the deployment of the Ministry of Finance, the Ministry of Education will carry out a performance evaluation of $100 \%$ of its project expenditure in 2016. At the same time, it has selected four major projects as its key self-evaluation projects: the "overall promotion of the construction of first-class universities and first-class disciplines", "the improvement of basic conditions for running schools in central universities", "education abroad" and "education abroad". The special funds for evaluation exceed 30 billion yuan, and the evaluation results will be submitted to the Ministry of Finance along with the final accounts of the department. The second is to combine the special system with the comprehensive system. For example, the Ministry of Education has not only formulated a series of special budget performance management systems such as "Opinions of the Ministry of Education on Promoting Budget Performance Management", but also issued a "Notice on Reforming and Perfecting the Budget Allocation System of Central Universities" together with the Ministry of Finance to improve the basic expenditure system and reconstruct the project expenditure system. At the same time, it has also formulated a comprehensive system similar to the Ministry of Education's project funding management approach, and has formulated and issued specific management measures or operating rules for all pilot projects that are included in the performance evaluation.

\subsection{Adhere to the Combination of Internal and External, Improve the Objectivity of Performance Evaluation}

In the relevant performance evaluation methods or systems, the Ministry of Education and the Ministry of Finance generally require the combination of internal evaluation and external evaluation in specific evaluation operations to continuously improve the objectivity of budget performance evaluation [21]. One is to require budget units to selfevaluate. In the Guidelines for Internal Control of Economic Activities in Universities Directly under the Ministry of Education (for Trial Implementation) and Guidelines for Internal Control of Economic Activities in Units Directly under the Ministry of Education (for Trial Implementation) issued in 2016, there are separate chapters that explicitly require universities directly under the Ministry of Education and units directly under the Ministry to carry out selfevaluation of unit performance. The second is selfassessment of the organization department. The Ministry of Education has drawn up a budget performance management evaluation work plan, requiring budget units to adopt a combination of self-evaluation and third-party evaluation, entrust a fund supervision center, and integrate various forces including experts in industry technology, finance and other fields and social intermediaries to jointly carry out departmental performance self-evaluation. Third, budget units are required to actively cooperate with external evaluation. Support and cooperate with the Ministry of Finance and the Budget Evaluation Center of the Ministry of Finance to complete the spot check and review of the budget and budget performance management of related projects of the Ministry of Education.

\subsection{Adhere to the Combination of Front and Back, Pay Attention to the Application of Performance Evaluation Results}

Before performance evaluation, mandatory constraints are 
adopted, requiring budget units to add pre-constraint conditions when preparing and reporting departmental budgets. For all funds included in departmental budget management, performance targets (including output indicators, benefit indicators and satisfaction indicators) are required to be filled in as the premise and main basis for budget arrangement, so as to move the budget arrangement forward and further strengthen the target orientation of budget performance. In the process of performance evaluation, through certain evaluation indexes and procedures, strengthen process monitoring of budget units; After the performance evaluation, take the initiative to disclose the results of the performance evaluation, form an institutionalized arrangement that the evaluation results are linked to the budget, continuously increase the efforts to apply the results of the performance evaluation, and improve the credibility of the performance evaluation [22].

\section{Existing Problems}

\subsection{The Performance of the Legal System Is Relatively Scattered}

Judging from the actual development of foreign higher education financial expenditure performance evaluation work, the setting of evaluation indexes, the determination of evaluation standards, the use of evaluation methods, the specific implementation of evaluation work and the supervision and implementation of evaluation results need not only the government and other relevant departments to formulate a series of systems or policies, but also legislative support to ensure the timeliness of performance evaluation. Mature laws and system guarantees are the core of higher education performance evaluation. At present, China has formulated various financial expenditure performance management methods or systems from the central government to the local government. In these methods or systems, some directions or regulations on higher education performance evaluation have been mentioned more or less, and relevant opinions have also been issued. However, there is no definition of higher education financial performance evaluation in the form of laws, which makes the legal system of higher education financial performance evaluation more scattered and affects the degree to which university managers and government performance management departments at all levels attach importance to higher education financial performance evaluation [23].

\subsection{The Lack of Necessary Awareness of Performance}

Due to the long-term influence of the planned economy, China's financial expenditure has always been based on scale rather than efficiency as its basic objective. It lacks necessary supervision and assessment on the efficiency of the use of funds and the output results of financial expenditure, which leads to a serious phenomenon of "redistribution and light management" in the use of education funds in colleges and universities. In addition, in the management process of higher education funds, the finance department is responsible for the preparation and distribution of higher education financial expenditure budget, while the education department is only responsible for the management of education appropriations, which to a certain extent causes information asymmetry between the two departments, and to a certain extent weakens the enthusiasm of the education department for the performance evaluation of higher education financial expenditure. In recent years, with the continuous strengthening of performance management requirements, project units have paid more attention to performance evaluation. However, some units still have insufficient understanding of the significance of performance management and believe that performance evaluation is only a formality. In project management, emphasis is placed on capital execution and less on performance management, and "performance evaluation" is simply equivalent to "capital exhaustion". In performance self-evaluation, emphasis is placed on achievements and less on problems. The evaluation results are not objective enough to reflect the project performance [24]. Therefore, on the whole, at present, all circles of society still need to improve their understanding of the importance of financial expenditure performance evaluation in colleges and universities.

\subsection{The Scope of the Evaluation is Difficult to Clearly Determine}

As a quasi-public product, the development of higher education needs the common strength of government, market and society. At present, with the increasing development and demand of higher education, it is an inevitable trend to broaden the funding channels of higher education and to diversify the funding sources of higher education. Therefore, higher education funds include not only financial expenditure but also tuition income, donation income and income from providing social services, etc., which makes it more difficult to evaluate the performance of higher education financial expenditure, because financial education funds and nonfinancial education funds are sometimes used in combination, and it is difficult to separate the income generated by financial expenditure when measuring the output. This makes it difficult to clearly determine the evaluation scope in the performance evaluation process.

\subsection{The Lack of Specialized Performance Evaluation Management Department}

Although our country has been emphasizing the importance of financial expenditure performance evaluation, the Ministry of Education and the Ministry of Finance have also issued many relevant regulations and systems, which deserve high attention from universities. However, from the perspective of various colleges and universities, the financial department, the education department and the financial department within the colleges and universities are basically responsible for the performance evaluation of financial expenditure in colleges and universities, and there is 
basically no separate performance evaluation management department parallel to the financial department. As the financial department is mainly inclined to the work of fund balance and accounting in its ordinary work, it does not have enough in-depth knowledge of the teaching, scientific research, administrative management and other business matters involved in the performance evaluation of financial expenditure, and cannot provide accurate, effective and professional information at the first time during the performance evaluation, which has greatly affected the objectivity and accuracy of the evaluation results.

\subsection{The Evaluation Index Is Difficult to Determine Scientifically}

Reasonable index is the key factor to evaluate success or failure. In recent years, the Ministry of Finance and the Ministry of Education have issued a series of system documents on performance management, which are of great guiding significance to the performance management of higher education. However, in the grass-roots executive departments, the performance evaluation work is still in the exploratory stage. A mature index system has not yet been formed for application. There is no unified work guidance document and operating rules, especially the performance evaluation index. There is no innovation and breakthrough in the project personality level. There is no index system that conforms to the project personality and completely reflects the project performance. This is not conducive to the full development of the performance management work [25].

\subsection{The Evaluation Content Is Difficult to Quantify}

Performance evaluation of financial expenditure of higher education generally requires a large amount of basic data support. However, due to the particularity of the non-profit institution of higher education, its output is students and scientific research achievements, and its goal is to cultivate high-quality talents, and its duty is to provide social services. In addition, the realization of investment income of higher education often requires a long period, which determines that the output of higher education cannot be measured like the output of general economic units. The input-output ratio of higher education cannot be simply measured by monetary and economic indicators, which leads to the difficulty of providing complete and detailed information and data in the performance evaluation of higher education and increases the difficulty of implementing the performance evaluation of financial expenditure of higher education.

\subsection{Performance Evaluation Needs to Be Strengthened}

In recent years, although China's higher education financial expenditure performance evaluation has made certain achievements, from the actual situation, the performance evaluation still needs to be strengthened. First, when reviewing the higher education financial expenditure, only the legality and compliance are emphasized, but the expenditure performance is not evaluated from the perspective of economy, efficiency, effectiveness and fairness Second, in the process of performance evaluation, selfevaluation is the main method, and there is no corresponding supervision mechanism. The third is that the evaluation results are mostly mere formality, which is not really linked to the relevant allocation policies [26]. As a result, the performance evaluation of financial funds in colleges and universities has gradually become a form to cope with the inspection of higher authorities and has not produced any practical effect.

\section{References}

[1] The Ministry of Finance, "Trial Implementation of Measures for Evaluating the Effectiveness of the Use of Social, Cultural and Educational Administrative Funds", http://www.chinaacc.com/new/63/71/2006/3/ca029751943113 60026720-0.htm.

[2] The State Education Commission and the National Bureau of Statistics, "Monitoring System for the Implementation of National Education Funds", http://laws.66law.cn/law15464.aspx.

[3] The Ministry of Finance, "Measures for Evaluating the Efficiency of Cultural and Educational Administration and Financial Management and the Use of Funds", https://law.lawtime.cn/d621926627020.html.

[4] The General Office of the State Education Commission, "Key Points of Education Audit Work in 1998", http://www.moe.gov.cn/srcsite/A05/s7052/200402/t20040203 181291.html.

[5] The Ministry of Education, "Several Opinions on Establishing Economic Responsibility System and Strengthening Financial Management in Colleges and Universities", http://www.moe.gov.cn/publicfiles/business/htmlfiles/moe/s32 63/201001/80047.html.

[6] The Ministry of Finance, "Administrative Measures for Project Performance Evaluation of Educational, Scientific and Cultural Departments at the Central Leve", http://www.chinalawedu.com/falvfagui/fg22016/8761.shtml.

[7] The Ministry of education: http://cwc.njust.edu.cn/18/d0/c1376a6352/page.htm.

[8] The Ministry of finance: http://jcc.cpu.edu.cn/c8/0d/c4689a51213/page.htm.

[9] The State Council, "the 12th Five-Year Plan for the Development of National Education", http://www.moe.gov.cn/publicfiles/business/htmlfiles/moe/mo e_630/201207/139702.html.

[10] The Ministry of Finance, "the Performance Budget Management Plan (2012-2015)", http://www.gov.cn/zwgk/2012-10/30/content_2253898.htm.

[11] The Ministry of Education and the Ministry of Finance, "Opinions of the Ministry of Education and the Ministry of Finance on Strengthening the Management of Scientific Research Funds in Colleges and Universities Belonging to Central Departments", http://www.moe.gov.cn/srcsite/A05/s7052/201212/t20121217 181257.html. 
[12] The Ministry of Finance, "the Framework of Common Indicators for Budget Performance Evaluation", http://yss.mof.gov.cn/zhengwuxinxi/zhengceguizhang/201305/ t20130507_857159.html.

[13] The Ministry of Finance, "the Notice on Further Strengthening the Budget Implementation and Management of Fiscal Expenditure", http://www.czj.sh.gov.cn/zys_8908/zcfg_8983/zcfb_8985/ysgl _8986/ysglhczxy/201509/t20150916_155384.shtml.

[14] The State Council's, "Decision on Deepening the Reform of Budget Management System", http://www.gov.cn/zhengce/content/201410/08/content $9125 . \mathrm{htm}$.

[15] The Ministry of Finance,"the Measures for the Management of Budget Performance Targets of Central Departments", http://www.chinalawedu.com/falvfagui/22016/wa1506112710. shtml.

[16] The Ministry of education,"the Opinions of the Ministry of Education on Strengthening the Internal Audit Work in Institutions of Higher Learning Directly under the Ministry of Education", 03/20/content 2836848.htm.

[17] The Ministry of Finance,"the Notice on Reforming and Perfecting the Budget Allocation System of Central Colleges and Universities", http://www.gov.cn/zhengce/201511/26/content_5017073.htm.

[18] The State Council, The Ministry of Education,"13th Five-Year Plan for the Development of National Education", http://www.moe.gov.cn/jyb_xxgk/moe_1777/moe_1778/2017 01/t20170119_295319.html.

[19] The Ministry of Finance, "the Measures for the Administration of Performance Appropriations such as the Management Reform of Central Universities", http://finance.whu.edu.cn/info/1016/1855.htm.

[20] Cheng Sihao. "On Performance Evaluation of Financial Expenditure on Higher Education in China." SME Management and Science and Technology 2010.4C (2010): 157-157.

[21] Feng Hui, and Qi Wang. "Analysis on the Performance Management System of Higher Education." China's Higher Education 7 (2012): 18-21.

[22] Liang Fang, and Bai Yanqin. "Research on Performance Evaluation of Fiscal Expenditure on Higher Education." Journal of Xi 'an University of Petroleum (Social Science Edition) 23.2 (2014).

[23] Lu Wei. "Analysis of the Historical Evolution and Current Situation of China's Public Education Expenditure Performance Evaluation System" Economic Research Reference 92 (2006): 25.

[24] Xiaobo Yang, Li Yonghua, and Song Jinjie. "Problems and Countermeasures in Performance Evaluation of University Financial Expenditure-An Empirical Analysis Based on 11 Key Universities in Hebei Province." Friends of Accounting 5 (2015): 97-100.

[25] Zhang Xiang. "Problems and Countermeasures in Performance Evaluation of China's Higher Education Fiscal Expenditure." Modern Economic Information 5 (2018): 270270.

[26] Yuan Jian. "Predicament and Prospect of Higher Education Performance Evaluation." Jiangsu Higher Education 1 (2014): 58-60. 